\title{
Why Should I Stay? Prediction on Factors Influence Employee Intention to Stay in Fast Food Restaurants in Malaysia
}

Hazrina Ghazali and Nurnabiha Roslan

To Link this Article: http://dx.doi.org/10.6007/IJARBSS/v11-i10/10906

DOI:10.6007/IJARBSS/v11-i10/10906

Received: 07 August 2021, Revised: 26 August 2021, Accepted: 25 September 2021

Published Online: 16 October 2021

In-Text Citation: (Ghazali \& Roslan, 2021)

To Cite this Article: Ghazali, H., \& Roslan, N. (2021). Why Should I Stay? Prediction on Factors Influence Employee Intention to Stay in Fast Food Restaurants in Malaysia. International Journal of Academic Research in Business and Social Sciences, 11(10), 221-235.

\section{Copyright: @ 2021 The Author(s)}

Published by Human Resource Management Academic Research Society (www.hrmars.com) This article is published under the Creative Commons Attribution (CC BY 4.0) license. Anyone may reproduce, distribute, translate and create derivative works of this article (for both commercial and non-commercial purposes), subject to full attribution to the original publication and authors. The full terms of this license may be seen at: http://creativecommons.org/licences/by/4.0/legalcode

Vol. 11, No. 10, 2021, Pg. 221 - 235

Full Terms \& Conditions of access and use can be found at http://hrmars.com/index.php/pages/detail/publication-ethics 


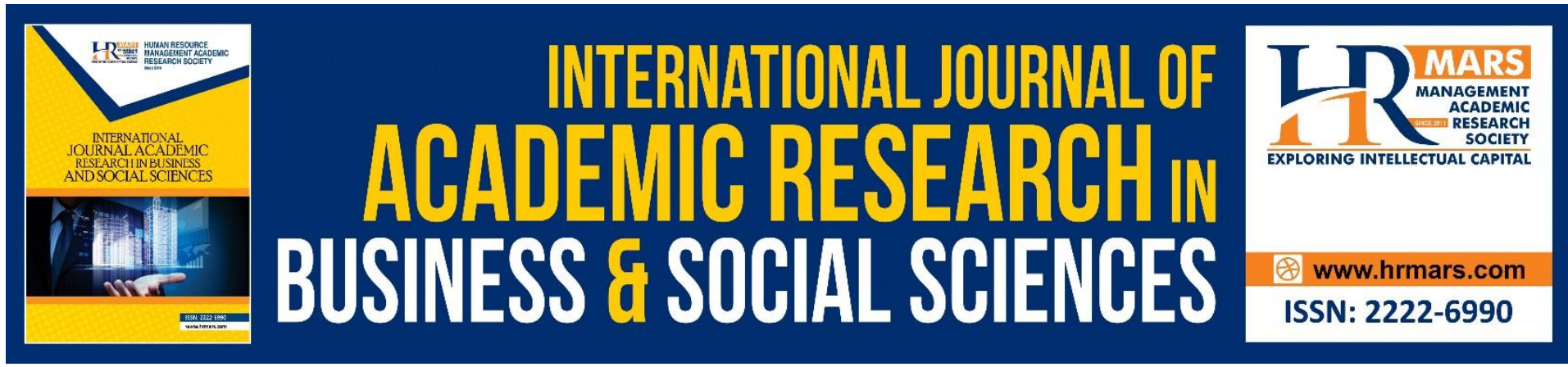

\title{
Why Should I Stay? Prediction on Factors Influence Employee Intention to Stay in Fast Food Restaurants in Malaysia
}

\author{
Hazrina Ghazali and Nurnabiha Roslan \\ Department of Food Service and Management, Faculty of Food Science and Technology, \\ Universiti Putra, Malaysia, 43400 UPM, Serdang, Selangor, Malaysia
}

\begin{abstract}
Fast-food industry is one of the most rapidly growing markets in Malaysia with high workforce jobs. Despite employees are the key and vital asset to the fast food industry's business, but employee turnover has been viewed as the industry's critical issue that needs attention. When the company loses talented employees, it will impact the companies' performance and operating cost. As such, the purpose of this study is to predict the potential factors that influence employees' intention to stay in fast food industry. In this study, the relationship between organizational commitments (OC), perceived supervisor support (PSS), reward system (RS) with employees' intention to stay were studied. This study employed quantitative research approach and a total of 216 questionnaires was distributed to the employees who were currently working in the fast food restaurants in Selangor, Malaysia. This study employed convenient sampling and 196 usable responses were returned for a 90.7 percent of response rate. The collected data was analyzed by using Statistical Package for Social Sciences (SPSS) version 23. A multiple regression was run to predict intention to stay with the three variables above and results found that $44.3 \%$ of variance in fast foods restaurants' employees was explained by organizational commitments (OC), perceived supervisor support (PSS), reward system (RS). Additionally, findings obtained from this study found that OC, PSS, and RS were positively correlated with employee's intention to stay with their current fast food restaurants. The findings are expected to help restaurant operators and human resource managers at the headquarters in developing and improving employee retention strategies in fast food restaurants and ultimately reduce turnover.
\end{abstract}

Keywords: Intention to Stay, Organizational Commitment, Perceived Supervisor Support, Perceived Organization Support, Fast Food Industry

\section{Introduction}

Fast food industry or quick-service restaurant (QSR) is a food establishment where consumers usually order or select items on the menu and directly pay before they eating (Wahab, 2017). According to Choong et al (2013) stated that the concept of fast food restaurant is the food prepared in the shortest time, convenience and served as fast as possible to customers. Besides that, fast food restaurant also provides constant set of menu 
and standard quality to lowest the time for the consumer to get the product information (Habib, Dardak, \& Zakaria, 2011).

Fast food restaurants are one of the rapid growth companies around the world in recent years and Malaysia is no exception to this development. The A\&W is the first outlet in Malaysia that introduce the concept of fast food, it was opened in Jalan Tuanku Abdul Rahman, Kuala Lumpur. From onion ring to double cheeseburger, fried chicken to pizza, fast food restaurants in Malaysia are like mushrooms after rain. Malaysia's output and the player landing in 1961 and has created his own fast food companies in Malaysia world (Naveed et al., 2016). According to Malaysia's Foodservice Annual 2017 reported that Malaysia has a wide variety of dining establishments, including full service restaurants, fast food restaurants, cafes, food stalls, food courts, eat-in bakeries, and pubs and bars to (Wahab, 2017). The researchers also mentioned that American franchises was arise throughout Malaysia and dominance the local fast-food sector such as QSR Brands (KFC), Golden Arches (McDonald's) and Secret Recipe Cakes \& Café dominate the consumer foodservice sector in Malaysia.

Malaysia's fast food business is made up of a varied range of food outlets that serve a variety of unique meals ranging from local to international. Burgers, fried chips, and sugarsweetened beverages, on the other hand, are conventional fast food meals. The fast food industry contributes for around 32\% of the total fast food outlets in Malaysia, with 6000 fast food outlets available in the market today while the QSR (Quick Service Restaurant) or fast food market was valued at $\$ 493$ million (RM1.8 billion) domestically (Xiao et al., 2019).

Fast food is viewed as quick, instant preparation, acceptable priced and is an alternative to home cooked food (Goyal and Singh, 2007). Fast food restaurants nowadays well-equipped with upgraded facilities such as television, radio, $\mathrm{Wi}-\mathrm{Fi}$, and cable plug service to attract more customers. The improvement of food delivery and drive-thru assist customers for being faster and offering time saving. Besides, the increased consumption of fast food greatly influenced by the accessibility, availability and affordability of a product (Abdullah et al., 2014). Even though the price for every meal are fairly high but it is still affordable and easy to get because fast food restaurants is numerous and easy to access. The customer come to fast food restaurant to enjoy and appreciate the minimum services and cuisines but no one actually realizes the amount of stress of employees have to go through to serve customer and work stress.

\section{Problem Statement}

On the other perspective, fast food restaurants are frequently under pressure from rising costs and the challenges of high turnover. The quick service and fast casual segments have the highest average turnover and quick service has the most expensive average cost to hire. The quick service has $74 \%$ of average turnover which is highest than other types of restaurants (Restaurant Industry Report, 2016). The main reasons why many employees leave their jobs included insufficient monetary or non-monetary motivation, insufficient support from their senior colleague, adverse work environment, inadequate of training and development, absent of rewards for a good job, lack of leadership style, organization culture, climate of the organization, improper job design, insufficient compensation plans and deficiency of work life balance (Johari, 2012; Sanjeevkumar, 2012; Nashuki et al., 2014; Farhan, 2020). Thus, this research has a tendency to propose solution to these challenges by looking at the relationship between employees' intention to stay with organizational commitment (OC), perceived supervisory support (PSS) and reward system (RS). An organization needed high costs due to turnover which include advertising, recruiting, 
selecting, hiring and training for the new employees (Sinniah \& Kamil, 2017). When an employee resigned, other co-worker need to replace it by doing more job and they also need to responsible on many duties that they carrying out. At the end, this situation indirectly lead employees to reduce their commitment in an organization and thus, increase the turnover intention as well (Chan, Yeoh, Lim, \& Osman, 2010). Therefore, high turnover intention will cause the organization to lose their core employees that have high degree of knowledge, skill and abilities (Liu, Liu, \& Hu, 2010).

In short, the purpose of this study is to investigate the possible factors that influence employees' intention to stay in fast food industry in Selangor, Malaysia. This study investigated employees' intent to stay with their current organization because understanding the factors retain employees with an organization may help with the improvement and implement of programs and interventions that allow employers to retain more of their current employees.

\section{Research Objective}

This study aimed to identify and predict possible factors that influence employee's intention to stay working in fast food restaurants in Selangor, Malaysia. The objectives are:

i. To identify possible factors that influence employee's intention to stay in fast food restaurants.

ii. To determine the relationship between identified factors and employee's intention to stay in fast food restaurants.

iii. To examine the most influential factors affecting employee's intention to stay in fast food restaurants.

\section{Research Question}

i. What are the possible factors that influence employee's intention to stay in the fast food restaurants?

ii. What is the relationship between identified factors and employee's intention to stay in fast food restaurants?

iii. Which are the most influential factors affecting employee's intention to stay in fast food restaurants?

\section{Literature Review}

\section{Organizational Commitment (OC)}

Organizational commitment is traditionally defined as "a strong belief in and acceptance of the organization's goals and values, a willingness to exert considerable effort on behalf of the organization, and a definite desire to maintain organizational membership" (Larkin, 2015). Besides that, organizational commitment involves employees' loyalty to organizations, their willingness to put effort into organization, the persistence to achieve personal goals with the organization, and the eagerness to continue work with the organization (Khaliq, Naeem, \& Khalid, 2016). Other definition of organizational commitment referred to as how much an individual grasp the qualities and objectives of an organization (Samudi, Slambolchi, \& Mobarakabadi, 2016).

Furthermore, organizational commitment of an employee is depending on the satisfaction in working place and absence of turnover intention. The loyalty that employees give towards the organization is largely depends on the extent to which they believe in the 
values, norms, orientations and aims of the organization and feel personally involved to makes the goals of organization achieved (Azeez, Jayeoba \& Adeoye, 2016). According to Salahuddin et al (2016) organizational commitment is a psychological state that hold employees and the organization and it can influence employees to make an option whether to continue stay as membership in the organization. Furthermore, a variety of positive employee attitudes and behaviors is based on organizational commitment and employees with high level of organizational commitment are believed will perform their job even better than those who are having lower organizational commitment (Rahman et al., 2016).

\section{Perceived Supervisor Support (PSS)}

Perceived Supervisor Support (PSS) is important to retain employees in the organization (Kalidass \& Bahron, 2015). Supervisor support can be defined as employees' general perspectives with respect to how much supervisors esteem their commitments and care about their well-being (Rathi \& Lee, 2015). According to Eisenberger et al., (2002), perceived supervisor support is defined as employee views about whether their "supervisors value their contributions and cares about their well-being." Perceived supervisor support is also considered a vital element of the performance assessment system, mediating between the perception of fairness of the employee and the competence of their supervisor (Eisenberger et al., 2002; Nassar \& Zaitouni, 2015).

Rathi and Lee (2015) also mentioned that supervisors express their support toward the employees by offering an explanation to their inquiries, giving a recommendation, guiding job development, and listening to their worries and grievance. In addition, Tate \& White (2005) quoted that "people leave managers, not organizations" is often cited when discussing about turnover intention. A manager who is viewed as supportive is probably to have employees who mean to remain in their present organization and it also a significant source in decreasing the possibility of work environment stressors and in ensuring employees' wellbeing (Teoh et al., 2016). The supervisor who can know, understand and treat their employees with justice, he or she can be greatly believed and preferred by employees (Seong, 2015). Employees consider their supervisors as representative who are working on behalf of organization, meaning that the ways supervisor treat his or her an employee will definitely affect the employees' feeling or thinking about how much their organization cares about their work performance that contribute to the successfulness of organization (Radford, 2013; Baran, Shanock, \& Miller, 2012).

\section{Reward system (RS)}

Reward system is an important mechanism for an organization to attract, keep, and motivate employees in order to accomplish the organization's goals. Rewards can be defined as awards given to employees on their performance and contributions to their organization, this can be a gift or incentive of any kind (Tiwari, 2015). According to Okioga (2012) defined reward system as anything saw important that is given to as acknowledgement for good commitment made and for performing undertakings well in a work environment. The term reward as something that offered by the organization to the employees as acknowledgement of their work as well as performance and something which is desired by the employees (Mwangi, 2015). The overall objective of reward system is to reward people without prejudice, equitably and systematically in line with their commitment to the organization in order to achieve the organization's goals (Sharew, 2017). As quoted by Puwanenthiren (2011) mentioned that "the reward system consists of all organization components - people, process, 
rules and decisions making activities involved in the allocation of compensation and benefits to employees in exchange for their contribution to the organization". Rewards can encourage individuals to achieve high performance and it also promote motivation and satisfaction to them (Zabouj \& Antoniades, 2015). It may also an effective strategy to keep the key performers in the organization and the reward also provide the employees to feel that they are recognized and needed. In addition, the employees will likely to feel their effort are well rewarded and motivate if the amount of the pay is worth to the work that they contribute to the organization (Khan et al., 2013). According to Terera and Ngirande (2014) mentioned that besides satisfying employees' needs and requirement, proper rewards system also provide them an opportunity to increase the performance of the organization.

\section{Intention to Stay}

Intention to stay is defined as employees' intention to stay in the present employment relationship with their current employer on long term basis (Johari et al., 2012). The researcher further mentioned that employees need to feel that their contributions to the organization are appreciated and they need to feel as part of family in the organization. Intention to stay is an inverse concept of turnover intention or intention to quit (AlBattrikhi \& Abu AlRoos, 2016). According to Pham and Pham (2016) described that the employees' level of commitment and their willingness to remain in an organization have been a mirror to the intention to stay.

Besides that, intention to stay is the positive conduct comparing to the intention to leave. Intention to stay actually when an employee had passion towards his or her job and they are willing to work in the organization for a long period. Intention to stay was a prediction that an employee will still remain to work with their employers and it also refers to the employee's conscious and intentional possibility to work with the same organisation (Nashuki et al., 2014). The figure below shows the conceptual framework for this study:

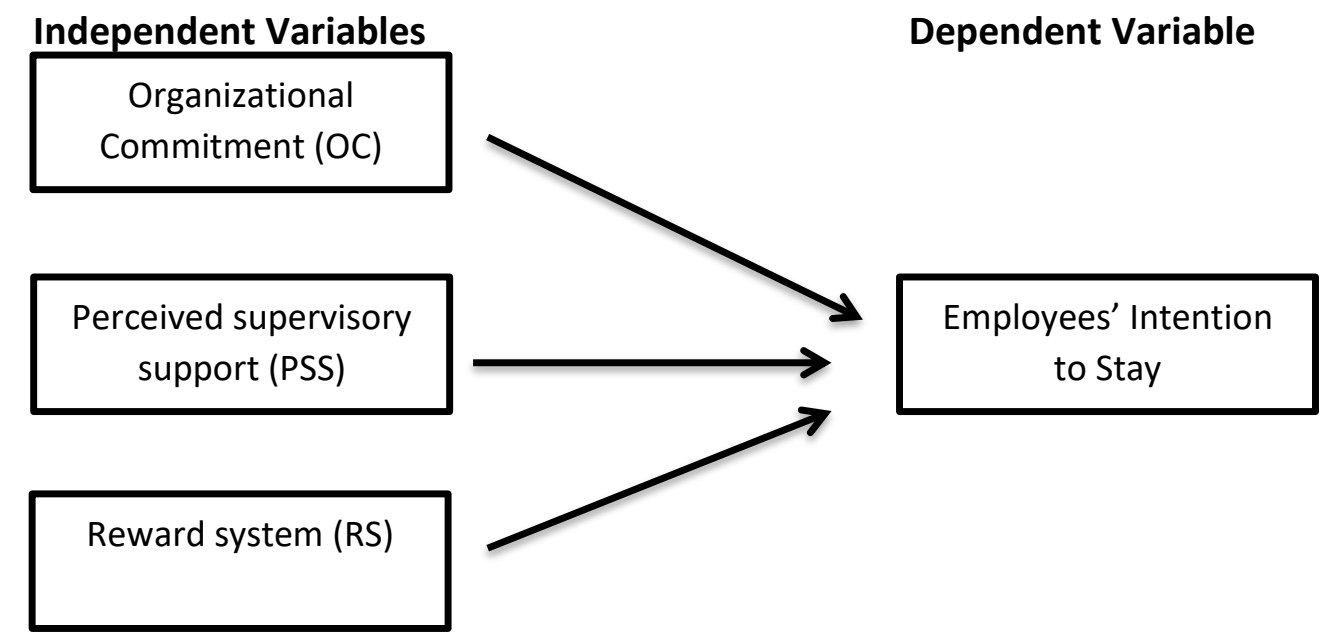

Figure 1: Conceptual Framework

\section{Methodology}

In this study, the research approach used was quantitative research. Quantitative research as it contained the structural questions wherein the respondent's preference that has been determine out and a wide variety of respondents are included. Hence, through quantitative studies, the non-experimental design which is correlational design was used. The 
respondents for this study consisted of the managerial and non-managerial employees from the selected fast food restaurants in Selangor. For the sampling method, this study used nonprobability sampling which is convenience sampling. A thorough protocol had been followed to ensure that the questionnaires were distributed after work hours and did not cause any disruption to the restaurants. The self- administered questionnaires were given to the managers on duty at the fast food restaurants and they helped the researcher to distribute them to their employees. The employees were advised that their participations were on voluntary basis and their identities will be kept anonymous. There were 216 copies of questionnaires distributed to the employees at the fast food restaurant in Selangor and after screening process, 196 usable questionnaires was returned back with the response rate of $90.7 \%$.

\section{Questionnaire Design}

There were three sections in this questionnaire, in section $A$ and $B$, the construct measurement which consist of the three independents variable includes organizational commitment, perceived supervisory support and reward system while dependent variable is employee intention to stay. In section A, the items asked in the organizational commitment (11 items) and perceived supervisory support (11 items) were adapted from the questions generated by Nasyira, Othman and Ghazali (2014). Then, the 10 items asked in the reward system was adapted from the questions generated by Johari, Tan, Adnan, Yahya and Ahmad (2012). Besides, in the Section B the items asked also adapted from Nasyira, Othman and Ghazali (2014). In this section, 5-point Likert scale was used where ' 1 ' equals "strongly disagree" and ' 5 ' equals "strongly agree". Lastly, in section $C$ the questions were all about the respondent's personal information such as age, gender, educational level, race, marital status, employment status, working hours per day, time of employment and current position. In this part, nominal and ordinal scale was used. The respondents required to choose only one answer from the options given and also the respondents need to state their own answers in the blank space provided.

\section{Results}

\section{Demographic Profiles}

From the table 2 below, it shows the respondent's demographic data consisted of gender, age, race, education level, marital status, employment status, the numbers of working years, working hours and lastly, respondent's current position in the fast food restaurant. Out of 196 respondents, it was found that majority of respondents were male employees with 121 respondents (62\%) while 75 respondents (38\%) were female. The respondent's average age was from the age group of 21 to 30 years with 130 respondents (66.3\%). The result also shown that Malay ethnic group was the largest group (82.7\%) working in the fast food outlets with 162 respondents. For educational level, majority of respondents held Sijil Pelajaran Malaysia (SPM, Malaysian Certificate of Education) with 147 respondents (75\%). The other educational levels such as Diploma was from the second highest with 34 respondents (17.3\%), followed by Bachelor Degree with 11 respondents (5.6\%).

Majority of the respondents were single where consist of 157 respondents (80.1\%), followed by married respondents with 38 respondents (19.4\%). In the term of the employment status of the respondents, it shows that 131 respondents (66.8\%) worked on full-time basis while about 65 respondents (33.2\%) were part time employees. In addition, the table 4 below also shown the figure year of working period of the respondents, it shows 
that 56 respondents (28.6\%) have work less than 6 months, followed by respondents who worked for 6-12 months with 50 respondents $(25.5 \%)$ and 49 respondents $(25 \%)$ that experienced working duration for 1-2 years. For the working hours, there were 119 respondents (60.7\%) who worked 8 hours per day. Then, followed by 42 respondents $(21.4 \%)$ who worked for 10 hours in the organization. Lastly, the current positions of respondents who participated in this research study were from various position in the fast food restaurants. The researcher found that from the result shown that the highest numbers of respondents were from services team with 138 respondents (70.4\%).

Table 1: Demographic profile of the respondents

\begin{tabular}{|c|c|c|c|}
\hline Variables & Category & Frequency & Percentages (\%) \\
\hline \multirow{2}{*}{ Gender } & Female & 121 & 61.7 \\
\hline & Male & 75 & 38.3 \\
\hline \multirow[t]{5}{*}{ Age } & Below 20 years & 50 & 25.5 \\
\hline & $21-30$ years & 130 & 66.3 \\
\hline & $31-40$ years & 12 & 6.1 \\
\hline & $41-50$ years & 3 & 1.5 \\
\hline & $51-60$ years & 1 & 0.5 \\
\hline \multirow[t]{4}{*}{ Race } & Malay & 162 & 82.7 \\
\hline & Chinese & 20 & 10.2 \\
\hline & Indian & 10 & 5.1 \\
\hline & Others & 4 & 2.0 \\
\hline \multirow[t]{5}{*}{ Educational level } & SPM level & 147 & 75.0 \\
\hline & Diploma & 34 & 17.3 \\
\hline & Bachelor degree & 11 & 5.6 \\
\hline & Master Degree & 2 & 1.0 \\
\hline & Others & 2 & 1.0 \\
\hline \multirow{3}{*}{ Marital status } & Single & 157 & 80.1 \\
\hline & Married & 38 & 19.4 \\
\hline & Others & 1 & 0.5 \\
\hline \multirow{2}{*}{$\begin{array}{l}\text { Employment } \\
\text { status }\end{array}$} & Full-time & 131 & 66.8 \\
\hline & Part-time & 65 & 33.2 \\
\hline \multirow{6}{*}{$\begin{array}{l}\text { How long you have } \\
\text { been working in } \\
\text { this restaurant? }\end{array}$} & Less than 6 months & 56 & 28.6 \\
\hline & 6-12 months & 50 & 25.5 \\
\hline & $1-2$ years & 49 & 25.0 \\
\hline & $2-3$ years & 25 & 12.8 \\
\hline & More than 3 years & 16 & 8.1 \\
\hline & Others & - & - \\
\hline \multirow{5}{*}{$\begin{array}{l}\text { How many hours } \\
\text { per day do you } \\
\text { work in this outlet? }\end{array}$} & 6 hours & 22 & 11.2 \\
\hline & 8 hours & 119 & 60.7 \\
\hline & 10 hours & 42 & 21.4 \\
\hline & More than 10 hours & 10 & 5.1 \\
\hline & Others & 3 & 1.5 \\
\hline What is your & Management team & 34 & 17.35 \\
\hline \multirow{2}{*}{$\begin{array}{l}\text { current position in } \\
\text { this outlet? }\end{array}$} & Services team & 138 & 70.4 \\
\hline & Production team & 24 & 12.25 \\
\hline
\end{tabular}

Note: $N=196$ 


\section{Identification of possible factor that influenced employees' intention to stay}

Table 2 presented the mean score and standard deviation for the independent variables (Organizational commitment (OC), Perceived supervisor support (PSS), Reward system (RS) and dependent variable (Intention to stay). Based on the 11 items asked for OC and PSS and 10 items asked for RS in the questionnaires, this study identified the factors that influenced employees' intention to stay towards their current jobs. From the table below showed that PSS has the highest mean score with 3.56 followed by RS with 3.49 and OC with 3.44. The result indicated that majority of the employees of fast food restaurants agreed that they have great support from their immediate supervisor and agreed that perceived supervisory support was the highest factor that generally implemented by the employer to influence employees' intention to stay.

Table 2: Descriptive Statistics for the variables

\begin{tabular}{lccl}
\hline & $\mathrm{N}$ & Mean & $\begin{array}{l}\text { Std. } \\
\text { Deviation }\end{array}$ \\
\hline $\begin{array}{l}\text { Organizational } \\
\text { commitment }\end{array}$ & 196 & 3.44 & .50558 \\
\hline $\begin{array}{l}\text { Perceived } \\
\text { supervisory } \\
\text { support }\end{array}$ & 196 & 3.56 & .55559 \\
\hline Reward system & 196 & 3.49 & .56285 \\
\hline
\end{tabular}

Scale: 1=Strongly Disagree, 2=Disagree, 3=Neutral, 4=Agree, 5=Strongly Agree

\section{Relationship between possible factors and intention to stay}

Based on Table 3, the results showed that all the possible factors have positive correlation to the intention to stay with the significant $p<0.05$. For the strength of the relation, it indicated that Reward system (RS) had a strongest correlation to the employees' intention to stay $(r=0.655, p<0.05)$, followed by Organizational commitment (OC) with $(r=0.474$, $p<0.05)$ and lastly, Perceived supervisor support with $(r=0.396, p<0.05)$.

Table 3: Correlation between Factors and Employees' Intention to Stay

\begin{tabular}{llc}
\hline Variable & $r$ & $p$ \\
$\begin{array}{l}\text { Organizational Commitment } \\
\text { (OC) }\end{array}$ & 0.474 & 0.000 \\
\hline $\begin{array}{l}\text { Perceived Supervisor Support } \\
\text { (PSS) }\end{array}$ & 0.396 & 0.000 \\
\hline Reward System (RS) & 0.655 & 0.000 \\
\hline *Correlation is significant at the 0.01 level (2-tailed).
\end{tabular}

Furthermore, in order to predict factors influence intention to stay among employees, the Multiple Linear Regression was done. Multiple Regression analysis was used in this study to examine the most influential factors that influence intention to stay. Based on table 4 below, the value of correlation coefficient (R) of independent variables (OC, PSS and RS) with the dependent variable (intention to stay) is 0.666 . Thus, it is shown that a positive and moderate correlation between three independent variables and dependent variable. Table 4 also presented the coefficient of determination from the $R$ square value which can use in explaining variance. The $R$ square value is 0.443 . Therefore, it indicated that about $44.3 \%$ of 
variance in dependent variable (intention to stay) was explained by independent variables (OC, PSS and RS). This implied that these three variables explained and predicted intention to stay among employees in fast food restaurants.

Table 4: Model Summary

\begin{tabular}{|c|c|c|c|c|c|}
\hline Model & $\mathrm{R}$ & R Square & $\begin{array}{l}\text { Adjusted } \\
\text { Square }\end{array}$ & $R$ & $\begin{array}{l}\text { Std. Error of the } \\
\text { Estimate }\end{array}$ \\
\hline 1 & $0.666^{a}$ & 0.443 & 0.435 & & 0.44504 \\
\hline
\end{tabular}

Based on Table 5, reward system (RS) and organizational commitment (OC) showed the significant value where $p<0.05$. This indicates that reward system (RS) and organizational commitment $(\mathrm{OC})$ influenced employees' intention to stay significantly. However, perceived supervisory support did not influence the employees' intention to stay significantly as the value was $p>0.05$. Only reward system (RS) and organizational commitment (OC) showed positive regression coefficient, with high level of these factors would increase the intention to stay. The result also showed that reward system has stronger effect (Beta $=0.617$ ) on intention to stay compared to organizational commitment (Beta $=0.162$ ) and perceived supervisory support (Beta $=-0.095)$.

\begin{tabular}{|c|c|c|c|c|c|}
\hline \multirow[t]{2}{*}{ Model } & \multicolumn{2}{|c|}{$\begin{array}{l}\text { Unstandardized } \\
\text { Coefficients }\end{array}$} & \multirow{2}{*}{$\begin{array}{l}\text { Standardize } \\
\text { d } \\
\text { Coefficients } \\
\text { Beta }\end{array}$} & \multirow[t]{2}{*}{$\mathrm{t}$} & \multirow[t]{2}{*}{ Sig. } \\
\hline & B & Std. Error & & & \\
\hline $\begin{array}{l}1 \\
\text { (Constant) }\end{array}$ & 0.692 & 0.241 & & 2.870 & $\begin{array}{l}0.00 \\
5\end{array}$ \\
\hline $\mathrm{OC}$ & 0.190 & 0.087 & 0.162 & 2.168 & $\begin{array}{l}0.03 \\
1\end{array}$ \\
\hline PSS & -0.102 & 0.081 & -0.095 & -1.249 & $\begin{array}{l}0.21 \\
3\end{array}$ \\
\hline $\mathrm{RS}$ & 0.649 & 0.077 & 0.617 & 8.393 & $\begin{array}{l}0.00 \\
0\end{array}$ \\
\hline
\end{tabular}

Dependent Variable: Intention to stay

\section{Discussion}

Overall, this research has fulfilled the three objectives of study on identifying and predicting possible factors influenced employee's intention to stay in fast food restaurants in Malaysia. Findings obtained from this study was able to answer research objective one which findings indicated that Organization Commitment (OC), Perceived Supervisory Support (PSS) and Reward System (RS) identified as factors that influence employees to stay working in fast food restaurants. One potential explanation for this is that employees in fast food restaurants in Selangor, Malaysia were well supported by their supervisors, had received good commitment from organization and received attractive reward. Reward system, as well as compensation, should not be disregarded, since most studies have shown that the negative effects of compensation can lead to significant worker dissatisfaction and problems in retaining employees. Findings of this study parallel with Osibanjo et al. (2014) which 
highlighted that employees retention were positively and significantly linked to compensation. Indeed, rewards system implemented in this fast food restaurants had encourage individuals to achieve high performance and promote motivation and satisfaction to them (Zabouj \& Antoniades, 2015).

In order to answer research objective two, Pearson Correlation analysis was used. Findings showed that all three factors have positive correlation with intention to stay with $p<0.05$. For the strength of the relation, it indicated that Reward System (RS) had a strongest correlation to the employees' intention to stay $(r=0.655, p<0.05)$, followed by Organizational Commitment $(\mathrm{OC})$ with $(r=0.474, p<0.05)$ and lastly, Perceived Supervisor Support (PSS) with $(r=0.396, p<0.05)$. Employees were looking for a company that would pay them more and offer them more appealing rewards and benefits. Employees will be more likely to stay with the company if the company offer them with attractive financial incentives. Findings of this study was parallel with previous studies (Nasyira et al., 2014, Nasir et al., 2019, Basford et al., 2012).

Lastly, research objective three which to predict the three factors that influence employee intention to stay in fast food restaurants was done by using the Multiple Regression analysis. Prediction on these three variables were reasonable and accurate because the Multiple regression analysis result revealed about $44.3 \%$ of variance in fast food restaurants employees were explained by these three variables - Organization Commitment (OC), Perceived Supervisor Support (PSS), and Reward System (RS). Therefore, these three factors can be suggested to implement and practice in fast food restaurants in order to increase employee's intention to stay.

Employees with high level of organization commitment have willingness and better motivation to remain with the organization. They also have higher contribution to perform and achieved the long-term organization's goals. Besides that, supervisors act as a representative for the employees between high level management and administration staff. The management will hear all the employee's problem through the supervisor. Employees with perceived stronger support and special care from their supervisors will encourage to have high staying intentions with the organization. In term of rewarding, employees who fully satisfied with their reward, get recognized tend to have higher motivation, high confidence level and more willingness to contribute to the organization. When the employees satisfied with their jobs, they tend to remain in the organization as long as possible.

In conclusion, fast food restaurant's employees in this study implied on receiving a good reward and having good relationship with their supervisor and organization which influence them to stay with their current job. It is agreed that employees with high level of intention to stay working with their current restaurants would have lesser intention to leave their jobs because they appreciate and feel obligation to investing more efforts in their job. At the end, it would create a feeling of attachments towards the organization. The findings of this study can be used to assist and guide the restaurant operators and human resource managers to implement specific retention strategies in the fast food restaurants. When the relationship among the variables are cleared and achieved, it is hoped to guide the managers when they encountered problems to keep their employees. Managers and restaurant operators must constantly keep in mind that employees will stay at the organization if it provides and offers attractive financial to them (Ramkumar, et al., 2016, Shepherd and Mathews, 2000, Jardine and Amig, 2001). 


\section{Conclusion}

After conducting this research, a better comprehension about the factors influenced employees' intention to stay in the fast food restaurants were identified. This research has achieved the objectives of study on identifying and predicting possible factors that influence employees to stay working in the fast food restaurants. In this study, three factors identified as Organizational Commitment (OC), Perceived Supervisory Support (PSS) and Reward System (RS) influenced employees' intention to stay in the fast food restaurants. Based on findings shows that there were a significant relationship between organizational commitment, perceived supervisory support and reward system and intention to stay among employees from the fast food restaurants.

Furthermore, findings of this study alert the fast food operators on importance of these three variables in retaining their employees. Findings also may provide benefits to managers or employers who intent to retain or keep their employees working with them. Since these three factors influenced employees' intention to stay, it is recommended for the management to give full attention on these factors in the organization, especially reward system (RS) as it was found to be the most influential factor. It is also important for supervisor or manager to monitor and supervise their employee by organizing employees' work, providing direct and indirect response to the employees' job tasks. At the same time, the employees also must be well rewarded by the employers to ensure that they are able perform their task effectively and would have a higher level of commitment towards the organization. Hopefully, findings of this study are helpful as it plays the important roles as a reference for the managers or restaurant operators to formulate effective strategies to retain employees from leaving the fast food industry. Employees' tenure may grow as a result of successful employee retention programs.

\section{Limitations}

There were some limitations that have been identified in completing this research's project. First of all, due to the time and budgetary constraint, this study has a small sample size. Malaysia consists of thirteen states but this study only covered Selangor state as sampling which affect the generalization issue. Findings of this study might not represent the whole population of fast food restaurants' employees in Malaysia. Secondly, this study only explored on three variables towards employees intention to stay and limited in examining all possible factors that lead to intent to stay. Other possible variables could be further explore to gain different view and perspective. Lastly, mixed method approach also suggested to conduct for future research to gain deeper understanding and more rich data.

\section{Corresponding Author}

Associate Prof. Dr. Hazrina Ghazali

Department of Food Service and Management, Faculty of Food Science and Technology, Universiti Putra Malaysia, Selangor, Malaysia.

Email: hazrina@upm.edu.my

\section{References}

Abdullah, N. N., Mokhtar, M. M., Abu Bakar, M. H., \& Al-Kubaisy, W. (2014). Trend on Fast Food Consumption in Relation to Obesity among Selangor Urban Community. ASEANTurkey ASLI (Annual Serial Landmark International) Conference on Quality of Life 2014, 
ABRA International Conference on Quality of Life, AQoL2014, 26-28 December 2014, Istanbul, Turkey.

AlBattrikhi, I. R., \& Abu AlRoos, D. A. (2016). Talent Management Practices as Drivers of Intention to Stay: Case Study (IT Companies in the Gaza Strip). Islamic University of Gaza

Azeez , R. O., Jayeoba , F., \& Adeoye, A. O. (2016). Job Satisfaction, Turnover Intention and Organizational Commitment. Journal of Management Research, 8(2).

Basford, T. E., Offermann, L. R., \& Wirtz, P. W. (2012). Considering the source: The impact of leadership level on follower motivation and intent to stay. Journal of Leadership \& Organizational Studies, 19(2), 202-214.

Baran, B., Shanock, L. R., \& Miller, L. R. (2012). Advancing organizational support theory into the twenty-first century world of work. Journal of Business and Psychology, 27(2), 123147.

Chan, B. Y., Yeoh, S. F., Lim, C. L., \& Osman, S. (2010). An exploratory study on turnover intention among private sector employees. International Journal of Business and Management, 5(8), 57-64.

Choong, S. N., Leong, C. J., Leong, W. X., Loh, F. Y., \& Teo, K. L. (2013). A study of employees' turnover intention among generation $Y$ in fast food industry. Retrieved from http://eprints.utar.edu.my/1025/1/BA-2013-0705291-1.pdf

Eisenberger, R., Stinglhamber, F., Vandenberghe, C., Sucharski, I. L., \& Rhoades, L. (2002). Perceived Supervisor Support: Contributions to Perceived Organizational Support and Employee Retention, Journal of Applied Psychology, Vol. 87 No. 3, pp. 565-573.

Ghazali, H., Nashuki, N. M., \& Othman, M. (2014). The relationship between Perceived Organizational Supports (POS) and intention to leave a job among employees of casual dining restaurants in Klang Valley area. Theory and Practice in Hospitality and Tourism Research, 425.

Habib, F. Q., Dardak, R. A., \& Zakaria, S. (2011). Consumers' Preference and Consumption towards Fast Food: Evidence from Malaysia. University Publication Centre (UPENA) and Institute of Business Excellence.

Johari, J. (2012). Promoting Employee Intention to Stay: Do Human Resource Management Practices Matter? Int. Journal of Economics and Management, 6(2), $396-416$.

Jardine, E., \& Amig, S. (2001) Managing Human Capital, Behavioral Health Management, 21(2), 22-26.

Kalidass, A., \& Bahron, A. (2015). The Relationship between Perceived Supervisor Support, Perceived Organizational Support, Organizational Commitment and Employee Turnover Intention. International Journal of Business Administration, 6(5).

Khaliq, I. H., Naeem, B., \& Khalid, S. (2016). A Study of Factors Affecting Organizational Commitment among Bank Officer in Pakistan. Journal of Business and Financial Affairs.

Khan, I., Shahid, M., Nawab, S., \& Wali, S. S. (2013). Influence of Intrinsic and Extrinsic Rewards on Employee Performance: The Banking Sector of Pakistan. Academic Research International, 4(1), 282.

Larkin. (2015). Job Satisfaction, Organizational Commitment, and Turnover Intention of online teacher in the K-12 setting. Doctor of Education in Instructional Technology Dissertations.

Liu, B., Liu, J., \& Hu, J. (2010). Person-organization fit, job satisfaction, and turnover intention: An emprical study in the Chinese public sector. Behaviour and Personality: An International Journal, 615-626. 
Mwangi, T. W. (2015). Perceived Relationship Between Reward Management Practices And Employee Retention In Insurance Companies In Kenya. University Of Nairobi.

Nassar, M., \& Zaitouni, M. (2015). "Perceived Performance Appraisal Justice In Egyptian Chain Hotels", International Journal of Culture, Tourism And Hospitality Research, Vol. 9 No. 3, pp. 329-345.

Nasyira, M. N., Othman, M., \& Ghazali, H. (2014). Predictors of intention to stay for employees of casual dining restaurant in Klang Valley area. International Food Research Journal, 21(3): 863-871.

Nasir, N. N. M., \& Ghazali, H. (2019). Predictors of Intention to Leave a Job for Employees of Casual Dining Restaurant in Klang Valley, Malaysia. International Journal of Academic Research in Business and Social Sciences, 9(5), 773-783.

Naveed, R. T., Ali, M., Adnan, M., \& Ahmad, N. (2016). Factors of Customer Relationship Management Affecting on Customers Satisfaction at Fast Food Industry in Malaysia. International Journal of Research in Business Studies and Management, 3(8), 32-41.

Okioga, D. K. (2012). The contribution of a developed Reward system on employee Retention; a case of Kisii Bottlers Limited: Kenya. European Journal of Business and Management, $4(16)$

Pham, L., \& Pham, L. (2016). The Effects Of Job Satisfaction And Organizational Commitment On Intention To Stay: Case Study At The Universities, Colleges In Bac Lieu City, Bac Lieu Province. The 10th International Days of Statistics and Economics.

Puwanenthiren, P. (2011). Reward system and its impact on employee motivation in commercial bank of sri lanka plc, in jaffna district. Global Journal of Management and Business Research, 11(4)

Radford, K. (2013). Two Sides of the same coin? An Investigation into factors influences employees intention to stay and leave. Griffith Business School.

Rahman, A., Shahzad, N., Mustafa, K., Khan, M. F., \& Qurashi, F. (2016). Effects of Organizational Justice on Organizational Commitment . International Journal of Economics and Financial Issues, 188-196.

Ramkumar, A., kumar, A., Kumar, S., Hazarika, S., Radhika, S., \& Shravanthi, V. K. (2016). A study on the factors affecting job hopping behaviour of its employees. International Education and Research Journal, 2(6), 97-99.

Rathi, N., \& Lee, K. (2015). Understanding the role of supervisor support in retaining employees and enhancing their satisfaction with life.

Restaurant Industry Report. (2016). Strategies for Reducing Turnover. Penn Foster.

Salahudin, S. N., Alwi, M. N., Baharuddin, S. S., \& Abd Samad, N. I. (2016). Generation Y: Organizational Commitment and Turnover Intention. International Conference on Business and Economics. Future Academy.

Samudi, S., Slambolchi, A., \& Mobarakabadi, H. (2016). A Literature Review On Organizational Commitment : A Comprehensive Summary. Applied mathematics in engineering, management and technology.

Sanjeevkumar, V. (2012). A Study On Employee's Intention To Stay In Public Companies, Kedah, Malaysia. Zenith International Journal of Business Economics \& Management Research, 2(4).

Seong, L. C. (2015). The Study On Factors Influencing Employee Turnover In E\&E Manufacturing Industry In Northern Malaysia. Universiti Sains Malaysia. 
Sharew, F. (2017). The Effect Of Reward Practices On Employees' Turnover Intention With Reference To Metals Industry Development Institute (MIDI). Addis Ababa University School of Commerce.

Shepherd, J. L., \& Matthews, B. P. (2000) Employee Commitment: Academic vs Practitioner Perspectives, Employee Relations, 22(6), 555-575.

Sinniah, S., \& Kamil, N. M. (2017). The Influence of Human Resource Practices on Turnover Intention: The Case of a Telecommunication Company in Malaysia. Malaysian Institute of Management.

Tate, R., \& White, J. (2005). People Leave Managers...Not Organizations! Action Based Leadership. iUniverse, London.

Teoh, K. R.-H., Coyne, I., Devonish, D., Leather, P., \& Zarola, A. (2016). The interaction between supportive and unsupportive manager behaviors on employee work attitudes. International Journal of Contemporary Hospitality Management, 28(4), 737-761.

Terera , S. R., \& Ngirande, H. (2014). The Impact of Rewards on Job Satisfaction and Employee Retention. Mediterranean Journal of Social Sciences, 5(1), 481-488.

Tiwari, I. (2015). An analysis of the factors affecting employee retention and turnover in the Irish hospitality industry. MA Human Resource Management.

Wahab, A. G. (2017). Malaysia Foodservice Annual . Kuala Lumpur: Global Agricultural Information Network.

Xiao, A., Yang, S., \& Iqbal, Q. (2019). Factors Affecting Purchase Intentions in Generation Y: An Empirical Evidence from Fast Food Industry in Malaysia. Administrative Sciences, 9, 4.

Zabouj, N., \& Antoniades, N. (2015). A study about the use of reward systems and employee motivation in a call centre. University of Gothenburg. 